Acta Universitatis Wratislaviensis • No 4046

Literatura i Kultura Popularna XXVI, Wrocław 2020

https://doi.org/10.19195/0867-7441.26.23

\title{
Miron Pukan
}

ORCID: 0000-0002-7657-038X

Prešovská univerzita v Prešove, Slovenská republika

\section{Medzikultúrny dialóg v súčasnej slovenskej dráme a divadle}

Kl'účové slová: autorský idiolekt, pol'ské, české a americké inonárodné divadelné kontakty, alternatívne divadlo, divadlo site specific, performancia

Słowa kluczowe: autorski idiolekt, polskie, czeskie i amerykańskie kontakty teatralne, teatr alternatywny, site-specific dramat, performans

Keywords: author's idiolect, Polish, Czech and American theatre contacts, alternative theatre, site-specific drama, performance

\section{Úvod}

V našej štúdii sa venujeme analýze medzikultúrnych procesov, kontaktov, podnetov, filiácií či konjunkcií amerického, pol'ského a českého divadla zhruba od sklonku šest'desiatych rokov minulého storočia po súčasnost' prostredníctvom umeleckej činnosti zahraničných súborov a ich tvorcov. Tie totiž podmienili vznik mediácie inonárodnej hodnoty v kontexte národnej divadelnej kultúry v konkrétnom prieniku do autorskej tvorby významného súčasného slovenského dramatika a prozaika Karola Horáka. Usilujúc sa naznačit' možné filiácie z príbuzných divadelných kultúr inonárodnej proveniencie, nemali by sme podl'ahnút' mechanickej „vplyvológii“. Preto sa usilujeme naznačit’ možné podnety z vonkajšieho prostredia inkorporujúcich sa do komplexu Horákovho rozsiahleho diela, ktoré neustále prechádza kreatívnou transformáciou a vyvoláva novú estetickú kvalitu jednak $\mathrm{v}$ rovine tvorby textu a jednak v inscenačných postupoch či v podnietení genézy úplne autochtónneho divadelného druhu (divadlo site specific, autorské divadlo, postmoderné divadlo, mediálne divadlo, divadlo happeningu či performancie a i.). 


\section{Filácie s americkým divadlom}

Vo viacerých responziách o inscenáciách tvorcu sa naznačuje možnost' výskumu komparačného vzt'ahu: divadelné dielo Karola Horáka, vrátane Študentského divadla Filozofickej fakulty Prešovskej univerzity v Prešove (ŠD FF PU) ${ }^{1}$ a amerického súboru Living Theatre. Autor pred rokmi poniektoré súvislosti viažuce sa k estetike tohto reprezentatívneho off a neskôr off-off broadwayovského telesa artikuloval vo svojej monografii Metamorfózy alternatívneho divadla (2009) ${ }^{2}$, pričom tvrdil, že na sklonku šest'desiatych a sedemdesiatych rokov 20. storočia neprišiel s inscenáciami Living Theatru do priameho diváckeho kontaktu. Ak by sme aj uvažovali o akýchsi bližších či vzdialenejších reláciách $\mathrm{s}$ jeho estetikou, žiada sa pripomenút' atmosféra tohto obdobia predovšetkým v kultúrnej oblasti prinášajúcej nadnárodné, univerzálne hodnoty. Navyše, vd’aka vplyvu z viacerých umeleckých oblastí (hudobnej, výtvarnej atd'.) ju dokresl'ovali divadelné poetiky vynárajúce sa nečakane a nezávisle od seba na geograficky rozmanitých miestach a kontinentoch. Tieto podnety z Living Theatre rezonovali v kontexte študentského divadla nielen v spomínaných rokoch, ale sa stali konštantnou črtou jeho poetiky. Ilustrovat' by sme to mohli na antinaturalistických divadelných postupoch uplatňovaných vo viacerých verziách inscenácie Džury $(1968)^{3}$, ktoré sa dokonca osobitým spôsobom pretavili do „expresionistického herectva“ a prejavili sa aj v odpore ku klasickému divadelnému ,kukátkovému“ priestoru, ako aj voči konvenčnej narácii dovtedy štandardne prítomnej v dramatickom texte a jeho divadelnej konkretizácii. Zrejmá je rovnako aj preferencia neraz formálnych jednotiek vo svojbytnom divadelnom výraze prešovského ŠD FF UPJŠ (napr. absurdné vytváranie konfigurácie veže z l’udských tiel v Džure ako alúzia na obdobie pračloveka a mamutov).

1 Vzniklo v roku 1960 ako Divadlo poézie FF UPJŠ Prešov (DP FF UPJŠ Prešov) z iniciatívy asistentov Katedry slovenského jazyka a literatúry FF UPJŠ Prešov. „1960-1962 a 19651972 ako DP FF UPJŠ Prešov, 1962-1965 ako Divadielko poézie a hudby FF UPJŠ Prešov, 1973-1978 ako Študentské divadlo Socialistického zväzu mládeže FF UPJŠ Prešov, 1979-1996 ako Študentské divadlo FF UPJŠ Prešov (ŠD UPJŠ Prešov), 1996-2014 ako Študentské divadlo Filozofickej fakulty Prešovskej univerzity v Prešove (ŠD FF PU v Prešove), od roku 2015 ako Študentské divadlo Prešovskej univerzity v Prešove (ŠD PU)“. Podl’a D. Inštitorisová, Čítanie v mysli dramatika (Karola Horáka), Bratislava 2007, s. 147. Špecifickú črtu činnosti tohto súboru predstavuje v súčasnosti bezprostredný kontakt herec — divák, čomu napomohla aj osobitá „,technická“ situácia súboru: ŠD FF PU v Prešove získalo v roku 2008 priestor bývalej tanečnej skúšobne folklórneho súboru Torysa. V tomto priestore bolo frontálne umiestnené šest'desiat pohyblivých stoličiek, pričom na páse obdížnikového tvaru zhruba 20x4 metrov interpreti prezentujú svoje produkcie prostredníctvom neiluzívnej scény. Jej pozadie tvorí na čierno natretá umakartová stena so starými typmi radiátorov. Tieto prostriedky podporujú koncepciu neiluzívneho divadla, autentickej divadelnej komunikácie aj odmietnutím iluzívnosti štvrtej steny.

2 Pozri bližšie K. Horák, Impulzy, stimuly a modifikátory tvorby divadla alternatívneho typu, [w:] idem, Metamorfózy alternatívneho divadla, red. M. Pukan et al., Levoča 2009, s. 95-97.

3 Mala niekol'ko inscenačných variantov a remakov: 1969, 1970, 1971, 1972, 2009. 
Iné analógie s Livingom sa núkali — ako o nich uvažuje Karol Horák jednak v súvislosti s „metaforickou akciou“ hereckého kolektívu Džury a jednak $\mathrm{s}$ „,yyjadrením tém jednotlivých scén cestou dynamickej pohybovej kompozície

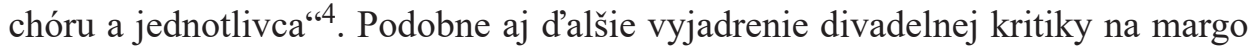
Antigony, ktorú Living uviedol v roku 1967, by sme mohli chápat' ako inšpiráciu pre činnost' prešovského súboru v Džure: „Fyzický výraz vychádzal skôr než z extatického psychického roznietenia hercov z prenesenia dôrazu na citlivý plastický a jogínskymi cvičeniami uvol'nený prejav tela. Pohybový výraz bol opät' nadradený textu“"5.

Badatel'ná je tiež inšpirácia týmito formalistickými koncepciami v dobovom umení, ako aj príklonom k poetike symbolizmu ${ }^{6}$. Svoju úlohu tu zohrali aj umelecké kontakty s dielom Erwina Piscatora a Bertolda Brechta vo vzt'ahu k epickému divadlu, ale aj k polemickému výrazu v období, ked' sa odmietala dobová „lož, klišé, štandard“. Na sklonku 20. storočia rozhodujúcu úlohu tu zohrával aj postoj divadelníkov — alternativistov k súdobému svetu, ktorý prechádzal prudkými turbulenciami. Zložitá situácia konca šest’desiatych rokov (zdôrazňujúc rok 1968) vyvolala pocit odcudzenia, ktoré nečakane prepadlo mladú generáciu z „odhalenia“ falošnosti spoločenských systémov na „východe“ i na „západe“, z radu domácich, regionálnych, celonárodných i celoštátnych káuz, ktoré otriasali etickými princípmi vtedajšej kultúrnej politiky. V konkrétnom priemete do činnosti súboru šlo napríklad o trvalú absenciu klasického divadelného kostýmu: herci ŠD FF UPJŠ používali konvenčný každodenný odev (trampky, jednoduché farebné bavlnené tričká a pod.), čo pretrváva dodnes. Súbor tvorili desiati až pätnásti interpreti, ktorí stabilne hrávali v tomto zložení takmer pät' rokov a priebežne boli dopĺn̆aní novými členmi, najmä po absolvovaní štúdia „starými“ hercami, ktorí odišli do praxe. Úzka spätost' kolektívu hercov vytvárala svojím spôsobom komunitu (divadlo komúny) tvorenú študentmi humanistiky, neraz z jedného študijného odboru. Všeobecná averzia členov súboru k obmedzujúcim spoločenským konvenciám vyžadovala od jeho vedenia, aby neprestalo hl'adat' nové prostriedky divadelného výrazu, a preto okrem ,pohybovo-slovných kreácií “ ŠD FF UPJŠ uvádzalo aj predstavenia druhu divadla poézie, v ktorom interpreti analyzovali osobitost' rytmickej štruktúry básnických textov a ich zvukovej realizácie, pričom vzhl'adom na erudovaných študentov v oblasti poetiky literárneho textu sa usilovali o hlbinnú analýzu sémantiky veršov a prekonávanie povrchných metód analýzy (Lermontovov Démon [1967], fragmenty z Válkových básnických zbie-

${ }^{4}$ Living Theatre, red. J. Kořán et al., Praha 1982, s. 33.

5 Ibidem, s. 31.

${ }^{6}$ Horák vo svojej prozaickej tvorbe priznáva určité inšpirácie napríklad poetikou postsymbolistu Andreja Belého. Podnety z dadaistického diskurzu odkazujú na inšpirácie, ktoré vd’aka historicko-spoločenskej situácii umenia socialistickej spoločnosti šest'desiatych rokov objavovali avantgardu v nových edičných vydaniach, zborníkoch, monografiách (spomeňme napr. dielo V. Nezvala, Moderní básnické směry, Praha 1969, s. 304 a pod.). 
rok Nepokoj a Milovanie v husej koži - V ako Válek [1970], ale aj remaky Mastersovho Pahorka [1966, remake 2014] a d'alšie).

Za najväčší prínos inonárodných divadelných kontaktov spájajúcich sa s koncepciou Living Theatre, ktoré našli svoj odraz aj v činnosti prešovského divadla, možno považovat' hereckú tvorbu - interpreti preferovali osobnostné herectvo podobne, ako herci amerického súboru, kde dochádzalo „k odstráneniu fiktívnych charakterov a priestoru. Bol to prvý krok smerom k divadlu, $v$ ktorom herci predstavujú samých seba“"7. Treba však poznamenat', a artikuluje to vo svojej štúdii aj Karol Horák, že nejde — povedané rečou umeleckej komparatistiky — o „geneticko-kontaktový vzt’ah“, ale o „divadelno-typologickú analógiu“, ktorá v spomínanom období bola citel’ná ako „výraz dobovej koncepcie jednej časti európskej či svetovej divadelnej alternatívy “8. Preto nie všetko v umeleckej činnosti prešovského súboru bolo odvodené od nejakého konkrétneho impulzu prechádzajúceho z tvorby inonárodného súboru, čo možno dokumentovat’ na samotnej fyzickej príprave interpreta, ktorá nemala svoje korene $\mathrm{v}$ jogínskej príprave, ale $\mathrm{v}$ získavaní základnej fyzickej kondície. Tá totiž súvisela so športovými skúsenost’ami režiséra a vedúceho súboru $\mathrm{v}$ jednej osobe. $\mathrm{V}$ interkultúrnych vzt’ahoch totiž platí výrok Andrého Gida: „Literárny vplyv nič netvorí, len prebúdza,“9 ktorý možno bezprostredne vzt'ahovat' aj na d’alšie inonárodné podnety, filiácie či prípadné analógie s Horákovou dramatickou a divadelnou tvorbou.

Horákov melecký kontakt a jeho divadelných aktivít s kontextom dobového západoeurópskeho alebo svetového divadla, pochopitel'ne, nereprezentujú iba filiácie tvorcu so spomínaným Living Theatre. $Z$ autorových reflexií ${ }^{10}$ vyplýva, že jeho pomerne intenzívny recepčný zážitok sa spája s divadelnou poetikou d’alšieho amerického súboru Bread and Puppet Theatre. Karol Horák naznačuje súvislosti medzi divadlom komúny tohto amerického súboru a osobitou „komúnou“ vysokoškolákov ŠD FF UPJŠ, ktorí tvorili špecifickú homogénnu skupinu, ktorá $\mathrm{v}$ šest'desiatych rokoch minulého storočia $-\mathrm{s}$ istým presahom do nasledujúceho desat'ročia - fungovala ako jedna z osobitých komunít usilujúca sa o moderný divadelný výraz netypický pre dobovú socialistickú kultúru. V naznačených intenciách bude pravdepodobne závažnejšie upozornit’ na osobitú poetiku tohto divadla, ktoré pracovalo s bábkou ako so signifikantným výrazovým objektom v jej rozličných typoch, vel'kostiach a osobitých modifikáciách ${ }^{11}$. Dramatik a režisér opisuje svoj recepčný zážitok z kultovej divadelnej produkcie Bread and Puppet Theatre Volanie l’udu po mäse (1968). Výtvarný aspekt tejto inscenácie sa v jeho

7 A. Aronson, Americké avantgardni divadlo, Praha 2011, s. 61.

${ }^{8}$ K. Horák, Metamorfózy..., s. 96.

9 Living Theatre..., s. 33.

10 Pozri bližšie K. Horák, Metamorfózy..., s. 70-142.

11 Bábky a masky, inšpirované všetkými výtvarnými kultúrami sveta, používali tvorcovia tohto telesa v klasickom slova, zmysle a vo všetkých možných vel'kostiach, od prstových bábok až po obrovské, niekol'kometrové monštrá, k obsluhe ktorých treba niekol'ko desiatok l'udí. Divadlo vyvíjalo silnú protivojnovú aktivitu predovšetkým v období protestov voči vojne vo Vietname. 
tvorbe prepojil na autopsiu s bábkovým divadlom $\mathrm{v}$ detstve, ked’ účinkoval ako žiak v otcovom bábkovom súbore Národnej školy v Teplej (okr. Banská Štiavnica) ${ }^{12}$. No rovnako aj v prípade Bread and Puppet Theatre nerecipoval vo svojej d’alšej tvorbe „Všetky“ prvky z tejto inscenácie, povedzme napríklad formu pouličného divadla. Takýto druh divadla $\mathrm{v}$ dobovom kontexte sedemdesiatych rokov 20. storočia totiž nebolo možné v ČSSR verejne realizovat'. Až neskôr, po prevrate, uviedol súbor pod jeho vedením niekol'ko produkcií v uličných priestoroch mesta či v d’alších exteriérových prostrediach. K danej divadelnej forme sa na inej štylistickej úrovni síce vrátil až po rokoch, no poučenie z tohto „výtvarného typu divadla“" bolo evidentné v nasledovnej činnosti prešovského súboru, predovšetkým v inscenáciách $V$ ako Válek (1970) a do určitej miery aj v druhej verzii Démona (1968):

V Schumannovom divadle sú postavy (maska a kostým), gesto a zvuk (výroky a reč, hluk, hudba) nezávislými zložkami v napätom sútoku. To naznačuje nielen audiovizuálna rovnost', ale aj prístup k zvrhnutiu nadvlády slova — či už ako expozícia myšlienok postáv alebo ich citov [...] alebo autorovej filozofie - bez obetovania významu ${ }^{13}$.

Pri uvedených komparačných analýzach by azda nebolo adekvátne, ak by sme preferovali len vonkajšie znaky spomínaných podnetov. Práve citované vyhlásenia lídra Bread and Puppet Theatre Petra Schumanna mieria k hlbšiemu podložiu činnosti tvorcov i jednotlivca umeleckého diela. Sú pre nás príznakové z ideového, estetického, ako aj etického hl'adiska — vzt’ahuje sa to jednak na ich koncepciu jednoty života a umenia a jednak na Schumannov výrok — „divadlo je potrebné ako chlieb“, ktorý vo svojom umeleckom prehlásení d’alej rozvíja cez hyperbolizované sémantické prezentovanie chleba, rituálu, bábky, masky a pod.:

Staré rituály spojené s pečením, jedením a podávaním chleba, boli zabudnuté. [...] Chlieb vám pripomenie svätost' pokrmu. Chceme, aby ste pochopili, že divadlo nemá ešte ustálenú formu, ani nie je miestom obchodovania, ako si to myslíte, kde zaplatíte a niečo dostanete. Divadlo je niečo iné. Je skôr ako chlieb, ako nutnost'. Divadlo je formou náboženstva. [...] Buduje vlastný rituál, kde sa herci usilujú povýšit' svoj život na čistotu a extázu dejov, na ktorých sa zúčastnia ${ }^{14}$.

\section{Filácie s pol’ským divadlom}

Ozrejmovanie umeleckých konjunkcií Karola Horáka s kontextom pol'ského divadla rovnako nemôžeme realizovat' mechanicky, interpretovat' ho bez hlbších súvislostí. Preto našu rekonštrukciu fenoménov viažucich sa $\mathrm{k}$ danej problematike podrobíme komparácii vychádzajúcej aj z časových siločiar, v ktorých spomínané kontakty prebiehali.

12 Pozri bližšie ibidem, s. 87-89.

13 Ibidem, s. 88.

14 Divadlo chléb a loutky, / Scénografie č. 30, red. V. Ptáčková, Praha 1972, s. 3. 
Horákova spolupráca s kultúrnym kontextom pol’ského divadla nebola jednorazová ani náhodná. Súvisela s jeho inklináciou k „modernému divadlu“ sklonku šest'desiatych rokov minulého storočia, ked' prišiel do kontaktu s pol'ským divadlom tohto typu ako účastník divadelných festivalov predovšetkým vo Vroclavi a neskôr aj v Krakove. Pochopitel'ne, že spočiatku to boli podnety divácke, no na ich základe dochádzalo v jeho koncepcii divadla k výraznej transformácii. Zjednodušene by sme mohli konštatovat”, že šlo o „prestup“ od drámy budovanej na verbálnej zložke k dramatickému textu, ktorý bol iba jednou zo zložiek divadelnej syntézy, teda od divadla budovaného na verbálnej informácii k štylizovanému fyzickému divadlu poučeného napr. postupmi Grotowského divadla.

V Horákových inscenáciách prešovského študentského divadla poučených predovšetkým spomínanou Grotowského koncepciou tzv. chudobného divadla sa v tomto období začali postupne objavovat' divadelné mizanscény s účast'ou neživých animovaných predmetov pohybujúcich sa v horizontálnej a vertikálnej rovine, v prepojení na kolektív živých hercov. V tejto symbióze tak vzniká osobitá poetika napájaná síce na spomínané dva inonárodné kultúrne impulzy, no autentická práve preto, že jej estetický valér je bytostne utváraný na hodnotách národnej kultúry, zjednodušene povedané divadla fyzického, pantomimického, mejerchol'dovského a podobne. Možno konštatovat', že ide predovšetkým o nadväzovanie na európske avantgardné tendencie: nájdeme tu spojnicu s divadlom poézie, pantomímy, s prvými pokusmi postmoderny atd'. Tento medzikultúrny proces - ako sme uviedli - pomáhal Horákovi „odliterárnit“" divadlo a presunút' ho bližšie k divadlu — ako to označil jeden zo slovenských kritikov — „totálnemu“.

Hoci v období normalizácie neboli kontakty medzi československou a pol’skou alternatívnou divadelnou kultúrou, pochopitel'ne, samozrejmostou, neznamená to však, že slovenská divadelná tvorba $\mathrm{v}$ danej vývinovej etape prestala žit', vyvíjat' sa, hl'adat' modus vivendi svojej existencie. Fragmenty materiálov týkajúce sa techník Grotowského „,elostného hereckého aktu“ či „svätého herca“, spojené s už avizovanou koncepciou tzv. chudobného divadla (ktoré v prípade prešovského súboru bolo vzhl'adom na svoje materiálne možnosti rovnako chudobným v prenesenom ponímaní Jerzyho Grotowského i utilitárnom význame), sa pre interpretov ŠD FF UPJŠ stali silným myšlienkovým i divadelným impulzom. Jerzy Grotowski vo svojej štúdii K chudobnému divadlu (Ku teatrowi ubogiemu, 1965) okrem iných filozoficko-teatrologických postulátov charakterizujúcich divadelnú koncepciu a metódu, uvádza:

Prostredníctvom postupnej eliminácie všetkého, čo sa dalo zo scény odstránit', akoby experimentálne, sme dospeli k názoru, že divadlo môže existovat' bez líčenia, bez autonómneho kostýmu a scénografie, bez odlíšenej scény, bez hry svetiel, hudobného pozadia a pod. Ale nemôže jestvovat', ak nejestvuje vzt’ah herec - divák, ich uchopitel'né, bezprostredné, ,živé“ obcovanie. [...] Ukázalo sa, že tým, čo je divadelné, čo je v svojej teatralite akoby 'magické', fascinujúce, je schopnost' herca pretvárat' sa pred očami diváka z typu na typ, z charakteru na charakter, zo siluety na siluetu, chudobne, to značí iba pomocou vlastného tela a remesla. [...] 
A tiež sa ukázalo, že tak, ako postavy na obrazoch El Greca i herec prostredníctvom duševnej techniky sa môže rozjasňovat', 'iluminovat', stavat' sa 'psychickým' svetlom ${ }^{15}$.

Tieto inšpirácie počas spomínaného normalizačného obdobia, presnejšie v polovici sedemdesiatych rokov, našli prostredníctvom členov súboru poučených jeho lektúrou a poetikou živnú pôdu napríklad v inscenácii Fragmenty (1974), konkrétne v jej prvej časti. V modifikovanej podobe ich možno vnímat' aj ako osobitnú divadelnú metódu, v tomto období na Slovensku v podstate jedinečnú (tréningy herca, nonverbálna výpoved' a i.). Jej osobnostné herectvo, výrazne transformované neraz aj ritualizáciou „nemého výrazu“ alebo výrazu s minimom slov, našlo originálny jazyk generačnej výpovede, v ktorej mladí interpreti vyjadrili vel'mi presvedčivo svoj vzt'ah k svetu. Povedzme, aj stvárnením existenciálnej situácie (spomeňme o. i. epizódy s nožom, so stolom, chlebom atd'.) ${ }^{16}$. Stopy týchto filiácí treba vidiet' aj v inscenáciách, ktoré sú svojou tonalitou „negrotovské“ — napríklad Živý nábytok (1975) a Tip-top biotop (1976), kde práve pohybová príprava na pozadí „tréningov“ inšpirovaných Grotowského postupmi našla svoju špecifickú podobu v rozpohybovanom generačnom recesívnom výraze.

Karol Horák na viacerých miestach svojej publikácie venujúcej sa problematike alternatívneho divadla pozitívne hodnotil zástoj kontextu pol'skej alternatívy vo vzt’ahu $k$ vývinu ŠD, k profilácii Akademického Prešova (AP) a vlastne i k svojej dramatickej a divadelnej tvorbe. Máme na mysli docenenie festivalov typu Otvoreného divadla vo Vroclavi (Festiwal Teatru Otwartego, 1969), krakovských Divadelných reminiscencií (Krakowskie Reminiscencje Teatralne, 1975) či poznaňskej Malty (1991). Takýto panoramatický kontext však bližšie nemodifikuje konkréta, ktoré môžu mat' osobitný význam pre formovanie osobnej či kolektívnej poetiky subjektu alebo ansámblu. V spomínaných vyznaniach sa dramatik odvolal aj na osobnú skúsenost' s Grotowského divadlom. V roku 1969 mal možnost' vidiet' v rámci vroclavského festivalu jeho výnimočnú inscenáciu Apokalypsis cum figuris (1969). Súčasne mal možnost' sledovat' fragmenty cvičení hercov v rámci divadelného workshopu, ktorý bol súčast'ou tohto podujatia. Tieto podnety sa dajú enumaratívne vyjadrit' prinajmenšom v nasledujúcom slede: nastolenie divadelného priestoru, ktorý má dispozície site specific, teda nedivadelného priestoru, a konaním hercov sa mení na autentický divadelný priestor „iný“ ako divadelný priestor klasického kukátkového portálového divadla. Z naznačenej charakteristiky následne vyplýva aj ,inakost“" divadelnej komunikácie na osi herec — divák. Ked’že išlo o bezprostredný kontakt, divák bol umiestnený $\mathrm{v}$ aréne dookola prázdneho priestoru, pričom počet divákov podliehal režisérovým pokynom, aby bol zabezpečený komorný charakter produkcie. Osobitnú zmienku si zaslúži interpretačná úroveň nevel'kého obsadenia tejto kultovej di-

15 J. Sloviak, J. Cuesta, Jerzy Grotowski, Warszawa 2010, s. 76-78.

16 Pozri podrobnejšie Horákovu hru Fragmenty, [w:] K. Horák, Slovo, gesto, obraz, tvar, Bratislava 1981, s. 111-147. 
vadelnej inscenácie. Hoci išlo o nedivadelné prostredie, kde herec bol odkázaný iba na malú sumu predmetov (bochník chleba, nôž, l’anový ručník, palica, lavór, vedro s vodou), technika hereckej kreácie interpretov bola jedinečná s vysoko zážitkovým dosahom. Vyplývalo to z kondičnej prípravy hercov, z maximálneho interpretačného nasadenia, $\mathrm{z}$ ktorého razilo úsilie presvedčit' partnera o svojej pravde, dramatické akcie mali presné mizanscénické riešenie, ktoré nepôsobilo umelo, hoci podliehalo dôslednej vycizelovanej príprave interpretov. $\mathrm{V}$ hracom obdížnikovom priestore čiernej sály pripomínajúcej bývalú tančiareň či gymnastickú miestnost', ktorej šero rozptyl’ovalo svetlo dvoch reflektorov, stvárňovali interpreti akcie s mnohovrstvovou symbolikou a premenlivými vzt’ahmi spontánne, vysoko emocionálne, ba priam až „baletne“ presne. Vnútorne pravdivé reakcie hercov aktivizovali orgiastickú a obradovú ostenziu l’udskej spoločnosti s jej potrebami „tvorenia a ničenia, viery a rúhania, osláv aj hýrenia“17. To všetko mali interpreti uskutočnit' ako proces „odhalenia pravdy mýtu prostredníctvom vlastnej autentickosti a samotnou prítomnost'ou“"18.

Jerzy Grotowski a jeho dvorný dramaturg Ludwig Flaszen nezakrývali, že predstavenie vznikalo postupne ako súčast' tréningov, cvičení, sústredení a že bolo chvíl'ami aj typom evidentne autorského divadla. Grotowski viedol cvičenia a sám aj cvičil, prijímal ponuky kolegov hercov a zároveň selektoval z množiny rozličných alternatív jednotlivých sekvencií tie nosné, ktoré neskôr tvorili základ uvádzaného premiérového variantu. Grotowski v tejto dobe hovoril o hereckej tvorbe ako o akte transgresie, pri ktorom, ako uvádza Jan Hyvnar, „dochádza k sublimácii a prenosu psychických obsahov ukrytých hlboko v podvedomí. Grotowski ich porovnáva s aktom spovede, ktorý je možný len na základe odhal'ovania niečoho z hercovho života“19. Tvrdil preto, že herec nehrá, ale preniká do oblasti vlastnej skúsenosti a analyzuje ich vlastným pohybom a hlasom. Musí vyhl'adávat' impulzy plynúce $\mathrm{z}$ híbky jeho tela a s plnou jasnost'ou ich nasmerovat' $\mathrm{k}$ istému bodu, ktorý je pre predstavenie nutný. Nie je to možné — ako konštatuje Grotowski bez úplnej prípravy, pretože herca vždy napadne: čo mám urobit? A ked’ uvažuje, čo by mal robit', nutne zablúdii ${ }^{20}$.

Nemenej zaujímavá bola aj textová zložka tohto diela, pretože na sklonku šest'desiatych rokov Jerzy Grotowski využil podnety prebúdzajúcej sa postmoderny a scenár Apokalypsis cum figuris skomponoval z fragmentov umeleckých textov rozličnej proveniencie. Boli to básnické diela Thomasa Stearnsa Eliota, časti próz Fjodora Michailoviča Dostojevského, ale aj zlomky a fabulačné jednotky zo Starého i Nového zákona. Takáto polysémantická „textová masa“ nepôsobila heterogénne, bola invenčne inkorporovaná do podoby dramaticky účinných replík, pre-

\footnotetext{
17 M. Semil, E. Wysińska, Slovník světového divadla 1945-1989, Praha 1998, s. 17.

18 Ibidem.

19 J. Hyvnar, Herec v moderním divadle, Praha 1999, s. 242.

20 Podl'a ibidem, s. 242-243.
} 
hovorov, monológov, dialógov, vyznaní, polemík etc. Napriek tomu textová zložka z hl'adiska kvantity nedominovala, tvorila organickú súčast' divadelného tvaru.

Pri signalizovaných filiáciách Horákovej tvorby s Grotowského divadlom treba však zdôraznit', že v činnosti prešovského študentského divadla neprestáva pôsobit' fungovanie aj d’alšieho kontaktového stimulu, akým je divadelná vízia svetoznámeho umelca — maliara, scénografa a režiséra Tadeusza Kantora. Znie priam neuveritel'ne konštatovanie, že vrcholné obdobie tohto tvorcu v polovici sedemdesiatych rokov 20. storočia malo - vzhl'adom na prebiehajúcu normalizáciu v Československu - u nás minimálnu dobovú recepciu. Svetoznáma inscenácia Mŕtva trieda (Umarła klasa, 1975), ako aj rad d’alších inscenácií avantgardného a experimentálneho divadla Cricot 2 rovnako, ako aj osobitá technológia genézy divadelného diela v Kantorovej „čarodejníckej dielni“, boli pre náš kontext takmer neznáme. Československá divadelná kritika síce recipovala spomínané podnety tohto divadelného typu, avšak ex post, teda s časovým desat' — dvadsat'ročným odstupom (Wielopole, Wielopole, 1980; Nech zmiznú umelci/Niech sczezna artyści, 1985; Nikdy sa tu už nevrátim/Nigdy tu już nie powrócę, 1988; Dnes sú moje narodeniny/Dziś sa moje urodziny, 1991 a d'alšie).

V činnosti prešovského študentského divadla, ako aj v kontexte Horákovej tvorby a Akademického Prešova možno zaevidovat' určité podnety tohto divadelného typu v prvom i druhom decéniu tohto milénia. Napríklad v inscenácii Človek etudovýalebo Konšpirácia alebo Od skúšky k predstaveniu (2013) v alúzii na Kantorov divadelný jazyk, na jeho pohyblivé rekvizity, nečakane animované divadelné prístroje s využitím ready mades (staré stoly, skrine, stoličky získané z fundusu študentských ubytovní atd’.) sa dostávali do styku so živými interpretmi v rozličnom funkčnom využití. Napr. ako predmety, na ktorých sa mohol hrat' príbeh „,minulosti“, ale aj rozohrávat' fabula s prítomným temporálnym určením signalizujúcim napätie medzi „starým“ a „moderným“, súčasným (možno aj budúcim). Využitie týchto predmetov ako objektov umožňovalo vyjadrit' „Všečasovost" a nadčasovost' traktovaného príbehu. V tejto súvislosti treba uviest' aj mobilný vysávač, ktorého kinetika $\mathrm{v}$ priestore $\mathrm{s}$ dial'kovým ovládačom a anonymným subjektom ním manipulujúcim vytvárala smerom $\mathrm{k}$ jednotlivým interpretom i ku kolektívu rozličné typy chronotopických metafor s rozmanitými pohybovými obrazmi l'udských tiel $\mathrm{v}$ civilnom priestore. Tie sa práve týmito aktivitami teatralizovali. Táto tendencia má svoje pokračovanie vo využití d’alšieho mobilného prostriedku, ktorý v prepojení na tento pohyblivý pragmatický predmet, pohybujúci sa horizontálne, našiel svoj protiklad v drone, teda $\mathrm{v}$ animovanom predmete $\mathrm{s}$ evidentnou vertikálnou dimenziou. Plnil aj významnú dramatickú funkciu a vyjadroval viacero sémantických situácií: od zábavnej cez transcendentnú, mýtickú, karnevalovú, agresívnu, hrozivú, imaginárnu atd'., ktoré rozohrávali členovia hereckej skupiny. Spočiatku neraz dokonca „zabezpečovanú“ anonymným „,moderátorom“, ktorý sa v jednej zo sekvencií prezentovaného príbehu objavil aj ako živá dramatická postava manipulátora. Ten riadil nielen spomínaný mechanický objekt, ale manipuloval s celým 
kolektívom, čím vytváral množinu dramatických situácií, v ktorých sa prejavila polysémantickost' tohto postupu. Navyše, podnecoval vznik dramatických udalostí, s ktorými sa, ako s problémovými, museli členovia kolektívu vyrovnat', pričom neraz sa ich riešenie stávalo performančným aktom. Ked’že je preň charakteristická pomerne nízka prediktabilita, býva odlišný od predstavenia k predstaveniu. Využitie predmetov $\mathrm{v}$ inscenácii, ktorá mala svoje korene $\mathrm{v}$ divadelnom workshope podobne, ako mnoho predošlých alebo aj d'alších — signalizuje však aj generačné, ironické (neraz i insitné) interpretačné timbre hercov relativizujúcich „lacné“, konzumné predmety ako prejav anticivilizačnej a antimeštiackej filozofie umeleckého kolektívu súboru. Nemožno ani v prípade tejto inscenácie hovorit’ o „absolútnej čistote“ Horákovej metódy, pretože „synkretický“ tvar vyplýval jednak — ako na to upozorňujú Viliam Marčok — z „kantorovského východiska“21 a Michal Babiak, „konvenujúc Horákovmu experimentovaniu a fenoménu študentského divad-

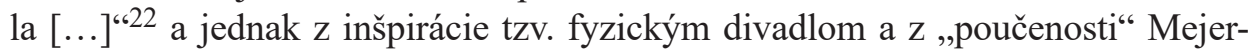
chol'dových biomechanických postupov.

Naznačené umelecké kontakty slovenského kultúrneho prostredia s pol’ským sa nevyčerpávajú už menovanými, pretože po Horákových skúsenostiach s vroclavským festivalom bolo ambíciou organizátorov AP pozývat' na toto fórum aj pol'ské súbory. Avšak „normalizačné“" sedemdesiate roky, ako sme už signalizovali, túto aktivitu pribrzdili. Bolo vylúčené, aby tvorcovia a ich súbory so svojím špecifickým timbrom teatrality — vzhl'adom na dovtedajšiu jedinú možnú metódu socialistického realizmu - host'ovali na tomto type podujatia, príp. na d'alších dobových festivaloch, akými boli napr. Divadlo mladých, Scénická žatva a pod.

Až po roku 1991 sa napr. v dramaturgii festivalu podarilo presadit' koncepciu pravidelného host'ovania pol'ských alternatívnych divadiel a ich tvorcov. Práve vo Vroclavi sa Karol Horák zoznámil s poetikou Lecha Raczaka, ktorý bol jedným zo zakladatel'ov (spolu s Tomášom Szymańským) kultového poznaňského Divadla Ôsmeho Dňa (Teatr Ósmego Dnia, 1964). Raczakova koncepcia divadla pôsobila v sedemdesiatych a osemdesiatych rokoch 20 . storočia elektrizujúco predovšetkým vd’aka zdôrazneniu spoločenskej funkcie generačného divadla a dôležitej formatívnej funkcie nasmerovanej $\mathrm{k}$ spoločenskému vedomiu pol'skej society.

Ked' bol Lech Raczak v roku 2006 vedením festivalu pozvaný ako lektor tvorivej dielne na jeho 40. ročník, s tvorivým kolektívom účastníkov workshopu začal pracovat' na príprave interpreta, potlačiac svoju minulú „,romantickú revolučnost". V divadelnej dielni s názvom Od biomechaniky k modernému interpretačnému výrazu - herec 2. divadelnej reformy i po nej staval na precíznej a uvedomelej práci s telom a hlasom herca, na ich kooperácii a symbióze. Po fyzickej rozcvičke, ktorá kládla dôraz na uvol'ňovanie celého hercovho tela, pokračoval

21 V. Marčok et al., Premeny dramatickej tvorby, [w:] Dejiny slovenskej literatúry III, Bratislava 2004, s. 327.

${ }^{22}$ M. Babiak, Slovenská dramatika na prahu 21. storočia, [w:] Kontexty alternativneho divadla II, red. J. Gbúr, K. Horák, M. Pukan, Prešov 2006/2007, s. 131. 
kolektívnymi etudami. Expresivitu javiskovej reči pretransformoval na javiskový pohyb. Na etudách s pracovnými názvami Prenáśanie skaly, Zvonenie v kostolnej veži, Pret'ahovanie sa povrazom, Lenivý kocúr sa usiloval priviest' účastníkov k chápaniu a prežívaniu každého pocitu a nálady iba prostredníctvom pohybového aparátu. Následne sa venoval tvorbe divadelného výrazu. Nacvičené etudy aktéri dielne obohacovali auditívnou zložkou (neartikulované zvuky, pazvuky, výkriky, vzdychy vyplývajúce $z$ autentického kinetického prejavu herca), ako aj rytmizáciou, melódiou či rozvíjaním viacerých techník dýchania. Napokon ponechal na účastníkov workshopu, aby vytvorili vlastné divadelné etudy s využitím osvojených výrazových prostriedkov 23 .

Divadlo ôsmeho dňa host'ovalo na AP až v roku 2013 (už bez jeho zakladatel’a) s plenérovou autorskou inscenáciou Archa, ktorú realizovali členovia súboru — podobne ako d’alšie produkcie uvádzané na tomto podujatí späté s verejným „nedivadelným“ priestorom — na rozsiahlej ploche pred novou budovou Divadla Jonáša Záborského v Prešove (DJZ) ${ }^{24}$. Svojou produkciou aktualizovali archetypálnu tému pôvodne biblickej Noemovej archy a akcentovali skutočnost', že žijeme v epoche tulákov a kočovníkov, ktorí putujú krížom-krážom, „ohrievajú duše spomienkami duchovného či etického, nebeského či geografického, pravdivého či

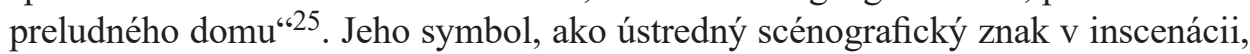
predstavovala mohutná okrídlená lod' - viacúrovňová pohyblivá scéna, ktorá sa v okamihu pretvorila napr. na lod' Enea alebo kubánsku plt vytvorenú z gumených člnov unášanú k pobrežiu Floridy. Pre protagonistov príbehu, pútnikov, predstavovala tiež akýsi dom, kde „ožívajú spomienky, svätyňa, kde sa každý obracia k svojmu Bohu, je miestom sveta, tanca a radosti“ ${ }^{\text {‘2 }}$. Lod’ oživená prítomnost’ou hercov, lesklých plachiet trblietajúco meniaca svoj tvar v svetle reflektorov sa presúvala uprostred publika, aby nakoniec rozvinula purpurové krídla a nadlho tak zachovala obraz neúnavných pútnikov smerujúcich do zaslúbenej zeme.

Recipovanie pol'ského alternatívneho divadla súviselo s Horákovou koncepciou využit' podnety viacerých divadelných druhov, inscenačných poetík pol'ského divadla, ktoré absentovali v československom kultúrnom kontexte poslednej štvrtiny 20. storočia. Popri generačnom, polemickom a kritickom divadle Lecha Raczaka bola zrejmá tendencia vniest' do kontextu prešovského festivalu aj estetiku ,výtvarného divadla“, aké reprezentovalo lublínske poetické divadlo Plastická scéna Lubelskej katolíckej univerzity (Scena Plastyczna KUL, 1969). Podnety tohto divadelného typu prichádzali, paradoxne, sprostredkovane zo susedných divadelných kultúr (Nemecko, Rakúsko či Mad’arsko). Táto divadelná estetika

23 Pozri bližšie D. Laciaková, Lech Raczak v prúdoch Akademického Prešova, [w:] Kontexty alternativneho divadla II, s. 252-254.

${ }^{24}$ Na jubilejnom 50. ročníku Akademického Prešova v roku 2016 sa súbor predstavil inscenáciou Summit_2.0 (2016) v réžii Jacka Chmaja.

${ }^{25}$ E. Wójciak, Arka, [w:] Teatr Ósmego Dnia, red. a fot. P. Skorupska, Warszawa 2007, s. 49.

26 Ibidem. 
bola pozoruhodná predovšetkým svojím vysokým estetickým štatútom, ktoré vd’aka umeleckému mágovi, výtvarnému umelcovi, autorovi, hercovi a režisérovi v jednej osobe Leszkovi Mądzikovi nadobúdalo podobu sugestívneho výrazu najvnútornejších záchvevov duše súčasníka ${ }^{27}$. Patrí k pokoleniu, ktorému bolo umožnené stretnút' sa bezprostredne s Grotowského divadlom a vidiet' vo Vroclavi prvú verziu už spomínaného divadelného predstavenia Apokalypsis cum figuris podobne, ako to bolo aj v prípade Karola Horáka. Táto skúsenost', ako o nej hovorí Janusz Degler,

bola síce skúsenost'ou, ale omnoho hlbšou než to, čo sa zvyklo označovat' ako prostá inšpirácia. [...] Mądzik, vstupujúc do divadla, si vybral cestu, ktorú Grotowski nazval „via negativa“. Najprv rezignoval na slovo, ale nevybral sa smerom k pantomíme. Dramatickú akciu zastúpila hra svetla a tmy, kontrapunktmi ticha a hudby, rozmanitými vizuálnymi prostriedkami tvoriacimi majstrovsky skomponovaný obraz. Ďalším, najtažším krokom [...] bola rezignácia na individuálne herecké roly zaobchádzat's hercami ako s rekvizitami alebo výtvarnými plastickými elementmi. Nakoniec sa mu podarilo vykreovat' vlastnú, úplne originálnu formu divadla, čo sa podarí málokedy a málokomu ${ }^{28}$.

Na rozdiel od Raczakových „,politicky“ sfarbených verbálnych polemík, Mądzikove inscenácie mali teda nonverbálny základ a ich katarzný účinok bol neraz ovel’a intenzívnejší než podnetná dráma či divadlo smerujúce $\mathrm{k}$ jemnej publicistickosti. Mądzik nezakrýval svoje krest’anské teologické východiská, tie však nepôsobili v rámci ,ikonickej verzie sveta“ tézovito, ale vd’aka sémanticky zaujímavým a výtvarne objavným znakom iniciovali zážitkový obraz vypovedajúci o existenciálnych otázkach človeka konca 20 . storočia, ktorý sa strácal v labyrinte hodnôt odchádzajúceho milénia. Divadelná komunikácia prebiehala ako prezentácia skrytých tajomstiev postáv, ktoré menili svoju podobu, transformujúc sa na hyperbolizované i minimalizované personálne jednotky, aby sa pokúsili recipienta orientovat' v bytostných otázkach zmyslu života a jeho premien. V dial'ave, ktorú vo svojom javiskovom kúzelníctve dokázal Mądzik vytvorit', blikalo svetlo nádeje poznania. Ono oslobodzovalo človeka od traumy neodvrátitel'ného konca. Takou inscenáciou bola napr. Vlhkost' (Wilgoć) uvedená na 41. ročníku AP (2007). Súčasne sa z tejto vizuálne pôsobivej, svetelno-akustickej prezentácie sveta nevytratil živý herec: jeho podoba prechádzala transformačnými procesmi, v ktorých strácal a nachádzal tvár, prezentoval sa ako „nahý herec“ vytvárajúci obraz spätý s biblickou tradíciou. Jeho prizdobovanie či prikrášlovanie prísunom výtvarných prvkov (líčenie, kostým a pod.) odkazovalo na stieranie hraníc feminínnych a mas-

27 V Mądzikových predstaveniach dominuje pohyb, obraz a nadstavbovú úlohu plní podl'a tvorcu svetlo. Jeho interpretácie sprevádza aj zvukový segment, akcie sú bezslovné. Diela prezentované na doskách Sceny Plastycznej KUL predstavujú filozofickú reflexiu o živote a jeho pretváraní. Táto reflexia často pochádza z konkrétnych zážitkov umelca. Žriedlom inšpirácie sú podl’a neho okrem iného úvahy sv. Jána z Kríža a sv. Terézie z Ávili, fascinujú ho práce Leonarda da Vinciho a vtedajších umelcov (napr. T. Kantora).

28 J. Degler, Teatr, [w:] Leszek Mądzik. Teatr, scenografia, warsztaty, fotografia, plakat, Kielce 2008 , s. 7. 
kulínnych postáv, ktoré sa v okamihu dokázali pretvorit’ na detské postavy. Takmer všetky predstavenia Leszka Mądzika — ako o nich vypovedá Janusz Degler:

spája otázka zmyslu nášho bytia. Na to isté sa pýta aj Witkacy, dokladajúc, že v hl’adaní odpovede na túto fundamentálnu otázku sa približujeme $\mathrm{k}$ Tajomstvu jestvovania. Usudzujem, že Scena Plastyczna patrí do jeho formuly divadla existujúceho mimo poňatia smiechu a plaču, životnej komiky alebo tragiky, čistého divadla zbaveného klamstva a čudného ako sen, v ktorom okrem nehôd nie je nič životne ospravedlnené, smiešne, vznešené či obludne presvecuje mierne, nemenné, z Nekonečna žiarivé svetlo VEČNÉHO TAJOMSTVA JESTVOVANIA ${ }^{29}$.

Žiada sa však poznamenat', že umelecké podnety s pol’ským divadelným kontextom sa nesústred’ovali iba na „velikánov“" pol'skej divadelnej kultúry. Na festivale AP sa zúčastnili aj súbory umelecky prínosné vzhl'adom na d’alší variant alternatívneho divadla, ktoré v slovenskom kontexte dovtedy absentovalo. Takým bolo napr. Cieszyńskie Studio Teatralne ${ }^{30}$ z pol'ského Tešína, ktoré na AP 2005 uviedlo adaptáciu 2. a 4. časti Mickiewiczových Dziadov s názvom Vychádzanie (Wschodzenie) v réžii Bogusława Słupczyńského. Mickiewiczovo kultové dielo romantizmu a mesianizmu má v histórii pol'skej kultúry bohaté kvantum interpretačných javiskových realizácií. Zdalo by sa, že takéto lokálne divadlo nemôže predostriet' novú a nekonvenčnú inscenačnú koncepciu majstrovského diela pol'skej i európskej literárnej spisby. Avšak invenčná scénografia, ktorej hracím centrom sa stala naturalistická chatrná búda s náznakom starobylého ikonostasu, ponúkla interpretom priam ideálny manévrovací priestor, $\mathrm{v}$ ktorom konali $\mathrm{v}$ ostrých a dynamických strihoch s využitím jeho vertikálnej i horizontálnej roviny. Za najväčší prínos pre slovenský divadelný kontext možno považovat' predovšetkým hereckú zložku. Interpreti pri stvárňovaní dramatickej postavy rezignovali na klasickú psychologizáciu či psychologickú skratku. Expresívnym pohybom, detailne vypracovaným verbálnym i speváckym prejavom dosahovali vysokú mieru štylizovaného výrazu, ktorý si v priebehu šest'desiat minútového predstavenia udržal razanciu a v prepojení na spomínaný scénografický prvok utváral autentickú komunikáciu medzi zdanlivo historickým artefaktom a jeho súčasnou konkretizáciou.

Za rovnako podnetné možno považovat' vystúpenie Realistického divadla zo Skiernievíc (Teatr Realistyczny Skierniewice) ${ }^{31} \mathrm{~s}$ inscenáciou Tra $-t a-t a \mathrm{v}$ réžii vedúceho súboru Roberta Paluchowského na festivale AP v roku 2005. V porovnaní s Raczakovým divadlom ide o súbor s evidentným politickým ostňom demaskujúcim aktuálnu spoločenskú tému, akou je účast' pol'ských, československých a slovenských vojakov v medzinárodných branných misiách. $V$ jeho poetike možno

29 Ibidem.

30 Alternatívne divadlo založené v roku 2000 Bogusłavom Słupczyńským v pol’skom Tešíne. Súbor do svojich inscenácií vplieta etnografické prvky, zvlášt' sa venuje preskupovaniu kultúr. Je činný umelecky a pedagogicky.

31 Vzniklo v roku 1995, jeho zakladatel’om bol herec a režisér Robert Paluchovský, ktorý bol zároveň organizátorom festivalu Hl’adanie alternatívy. Počas desiatich rokov svojej existencie súbor naštudoval niekol'ko desiatok inscenácií a zrealizoval viacero divadelných projektov opierajúcich sa zväčša o originálne texty formou autorského divadla s výrazným výtvarným akcentom. 
nájst' aj isté analógie so Scenou Plastycznou KUL, pretože bola budovaná na výraznej javiskovej metafore, akú v predstavení reprezentovali vel'ké igelitové vrecia naplnené špinavou tekutinou, ktorá sa počas „bojov“ medzi interpretmi aktivizovala. Z prebodnutých vriec striekala na hercov i publikum špina násilia. Pre väčšinu spomenutých pol'ských súborov je teda zrejmá divadelná „poučenost“" domácimi východiskami alternatívneho autorského divadla, čo potvrdzuje aj toto teleso.

S určitou nostalgiou treba rovnako zaevidovat' fakt, že pol'ské alternatívne divadlo prežívalo svoj umelecký rozlet predovšetkým v sedemdesiatych a sčasti aj v osemdesiatych rokoch minulého storočia. Máme na mysli už spomínanú koncepciu Kantorovho divadla, Raczakovu estetiku politicky angažovanej výpovede v Divadle ôsmeho dňa, Mądzikovu výtvarne koncipovanú estetiku Plastickej scény či Grotovského divadelnú líniu chudobného divadla a pod. K týmto súborom treba ešte pričlenit' jedno z reprezentatívnych pol'ských telies európskeho formátu Divadlo Akadémia pohybu z Varšavy (Teatr Akademia Ruchu, 1973). Je to možno paradoxné, no práve s týmto súborom sa organizátori prešovského festivalu usilovali pomerne dlhodobo nadviäzovat' kontakt. Preto do konfrontácie so slovenským kontextom alternatívnej divadelnej kultúry vstúpilo až v roku 2015 dvoma projektmi: Výrazne. V mlčaní (Wyrażnie. W milczeniu) a Č́nska lekcia (Chińska lekcja) v réžii Wojciecha Krukowského. Zaradenie tohto špičkového telesa do programu AP súviselo s charakteristickými znakmi jeho poetiky, ku ktorej ŠD FF UPJŠ v minulosti dlhodobo inklinovalo a zostalo jej v jednej zo svojich inscenačných línií verné dodnes už ako Študentské divadlo Prešovskej univerzity. Ide o

zámernú redukciu javiskovej akcie a rekvizít na potrebné minimum, rezignáciu na literárne dialógy a príbeh, neosobný charakter postáv, spojenie hereckej akcie s hudobnými fragmentmi, s útržkami slov, viet alebo s autentickými zvukmi (hluk ulice a pod.), analýzu technických a výrazových možností tela ${ }^{32}$.

Atakovaním postupov klasického repertoárového divadla a tzv. „dobre urobenej hry" od počiatkov svojej umeleckej činnosti prostredníctvom divadla performancie a happeningu prispeli $\mathrm{k}$ antimeštiackemu prístupu, výkladu i funkcii divadla. Tak napr. v Č́nskej lekcii využívajúcej performančné výrazové prostriedky a konceptuálny autorský prístup pät‘členný súbor zahral niekol'ko krátkych sekvencií trvajúcich od pät' do desat' minút, ktorých podstatnú črtu predstavovala formálna jednota pochádzajúca z oblasti jazyka vizuálneho divadla. Uvol’nené konanie členov súboru prechádzalo od privátneho, zvnútorneného výrazu do kondenzovanej, nezvyčajne fyzicky plastickej akcie ako kritická alúzia vyjadrujúca postoj obyvatel'skej neposlušnosti voči praktikám spoločenského systému, ktorý sa vymkol z kíbov. Podobne, ako v prípade väčšiny divadelných realizácií Akademie Ruchu, aj v tomto „formálna skúsenost' nevylučuje spoločenský odkaz ko-

${ }^{32}$ M. Semil, E. Wysińska, op. cit., s. 11. 
munikátu, ba naopak slúži k vydobytiu jeho podtextu“33. Alebo ináč: „umelecký radikalizmus a spoločenský odkaz nemusia stat'v protiváhe“334.

Ďalším pol'ským divadelným súborom alternatívneho typu divadla je aj krakovský súbor KTO orientujúci sa v súčasnosti predovšetkým na poetiku pouličného divadla, ktoré sa stalo jedným z pravidelne sa vyskytujúcich druhov divadla na prešovskom festivale. $V$ ostatných rokoch tu uviedol štyri pomerne svojbytné a umelecky podnetné inscenácie - Cervantesov Quixotage (2010), Saramagových Slepcov (Ślepcy) (2012), Chór sirôt (Chór Sierot) (2015) a Peregrinus (2018) všetky v réžii Jerzyho Zońa. Vzt’ahuje sa to aj na dva osobité lokalizácie čtyroch spomínaných produkcií vo fyzickom priestore „nedivadla“: prvú, druhú a štvrtú realizovanú v plenérovom prostredí mesta (v prvých dvoch prípadoch na verejnej ploche pred novou budovou Divadla Jonáša Záborského Prešov a v ostatnom na prešovskej pešej zóne $\mathrm{v}$ historickom jadre mesta), $\mathrm{v}$ tret'om prípade $\mathrm{v}$ športovej hale, kde bolo hl'adisko situované na palubovkách, modifikované na osobitý typ divadelnej komunikácie (vrátane komponovania dreveného skeletu, v ktorom i na ktorom rozohrávali interpreti dramatický príbeh).

Cervantesov Quixotage, ako aj Slepci vychádzali z kvalitnej literárnej predlohy, pričom dramatizácia a dramaturgicko-režijný výklad vo vzt’ahu k pretextu smerovali $\mathrm{k}$ hl'adaniu a nájdeniu adekvátneho priestorového i komunikačnému riešenia ako javiskovej metafory. Pri Cervantesovi išlo o vhodne scénograficky využité snové predmety s obrazným značením (veterné mlyny, postavy obrov, kinetické, na elektrický pohon sa premiestňujúce vozíky stvárňujúce Quijotovu Rocinantu a pod.). V pomerne rozsiahlom hracom priestore na tvrdej dlažbe, rozohrávajúc inscenáciu smerom k divákom obkolesujúcich scénický priestor, nečakane zarezonoval Quijotov príbeh ako podobenstvo o strate ilúzií a nekompromisnej konfrontácii sna a skutočnosti.

Hoci Slepci vo viacerých prostriedkoch využili skúsenost' inscenátorov s týmto mestským priestorom pred novou budovou DJZ, predsa len jeho zaplnenie radom pohyblivých nemocničných lôžok dokumentovalo základný tematický program inscenácie: vyjadrenie fenoménu slepoty súčasnej civilizácie na prelome nového milénia. Okrem individuálneho príbehu protagonistov so špecifickou, subjektívnou charakteristikou každého z nich, zrejmou bola aj rovina ideovej nadstavby základného príbehu, teda slepoty v prenesenom slova zmysle, vo vztahu k súčasného marazmu etických, svetonázorových a ideologických hodnôt. Plenérové inscenácie KTO predstavovali d’alší štýlový variant pol’ského alternatívneho divadla, ktoré permanentne hl'adá nové a nové podoby umeleckého výrazu a tento aspekt nie je vzdialený ani prešovskému festivalu.

K vel'kým prednostiam tohto podujatia patrí aj to, že v Prešove „debutovali““ prvýkrát v slovenskom kontexte viaceré pol'ské súbory so svetovo známym reper-

33 A. Rottenberg, Náčrty tvaru, [w:] Akademia Ruchu. Miasto. Pole akcji, Warszawa 2012, S. 148.

34 Ibidem. 
toárom. Okrem spomenutých uved'me tie, ktoré sa na ňom prezentovali po roku 2000: napr. Teatr im. W. Siemaszkowej Rzseszów: Rozbal'ovanie (Rozpakowaniel Deballage) (2000), réžia: Józef Szajna; Teatr Cogitatur Katowice: Witold Izdebski Aztec Hotel (2003), réžia: Witold Izdebski; Teatr Krzyk Maszewo: Hlasy (Gtosy) (2005), réžia: Marek Kościołek; Divadlo pohybu a obrazu Vel'ká Británia Pol'sko: Equaldoubt (2006), réžia: Sean Palmer (VB) a Agnieszka Błońska (PL); Teatr Porywacze Ciał Poznań: Kataryna Pawlowska OUN (2007), réžia: Katarina Pawłowska a Maciej Adamczyk; Akademia Teatralna im. A. Zelwerowicza w Warszawie, Wydział Sztuki Lalkarskiej Białystok: Bav sa, zmija, bav... (Baw się, żmijo, baw...) (2008), réžia: Agniezska Baranowska, Monika Kwiatkowska; Białostocki Teatr Lalek, scena studijna: Baldanders (2009), réžia: Marcin Bikowski; Teatr BOB Kraków: Hry Toporom (Zabawy Toporem) (2010), réžia: Anna Mazan; Teatr Praga Warszawa: Marius von Mayenburg Paraziti (Pasożyty) (2011), réžia: Tomasz Gawron; Teatr Nowy Kraków: Markíz de Sade Filozofia v budoáre (Filozofia w buduarze) (2012), réžia: Bogdan Hussakowski; Teatr Nowy Kraków: Dominik Nowak Vikend (Weekend) (2012), réžia: Iwo Vedral; Teatr MOMO Katowice: Marek Kołbuk Darček (Podarunek) (2013), réžia: Marek Kołbuk; Teatr Przedmieście Rzeszów: Aneta Adamska Príslub (Obietnica) (2015), réžia: Aneta Adamska; Mateusz Nowak Lublin: Spredu i zozadu (Od przodu i od tyłu) (2015), réžia: Stanisław Miedziewski; Teatr Ósmego Dnia Poznań: Summit_2.0 (2016), réžia: Jacek Chmaj, Teatr Przedmieście Rzeszów: Thomas Mann - Aneta Adamska Cesta (Droga) (2015), réžia: Aneta Adamska (2017), Teatr Kantor Wymiany Myśli Rzeszów: M. Adamiec Stojím na scéne (Stoję na scenie) (2018), réžia: Monika Adamiec.

Žiada sa poznamenat', že nie každé host'ovanie súboru bolo recipované v podobe konkrétneho „vplyvu“ na umeleckú tvorbu, artefakt či konkrétne divadelné dielo prešovského súboru. No v rámci spomínaného festivalu (pre jeho účastníkov a prinajmenšom aj pre kontext prešovského divadelného publika) boli hostujúce súbory vel'kou recepčnou príležitost'ou oboznámit' sa s kontextom pol'ského alternatívneho divadla, ktoré reprezentuje v spomínanom divadelnom type svetovú špičku.

\section{Filiácie s českým divadlom}

Ak hovoríme o podnetoch z umeleckých začiatkov Karola Horáka a umeleckých telesách, ktoré ho oslovili bud' svojím generačným výrazom alebo osobitou inscenačnou poetikou, nemali by sme obíst' československý, presnejšie český divadelný dobový kontext šest'desiatych rokov minulého storočia. Signalizovali sme jeho kontakty s divadlom poézie a s prvými scenáristickými i režijnými aktivitami v tomto druhu divadla. Vo viacerých teoretických prácach Horák zdôrazňuje svoje skúsenosti aj s amatérskym umeleckým prednesom, s jeho aktívnou účast'ou na vrcholných celoslovenských a celoštátnych podujatiach už počas vy- 
sokoškolských štúdií na FF UPJŠ Prešov, ako aj status vysokoškolského pedagóga - odborného asistenta $\mathrm{v}$ tejto inštitúcii, ktorý začal intenzívnu činnost' so súborom spočiatku Divadla poézie FF UPJŠ. Tieto súvislosti uvádzame aj preto, že host'ovanie českých súborov na popredných amatérskych sút’ažiach, prehliadkach či festivaloch $\mathrm{v}$ šest'desiatych rokoch, povedzme aj na celoslovenskej prehliadke zameranej na umelecký predes a divadlá poézie - Hviezdoslavov Kubín, bolo pre mladého vysokoškoláka neobyčajne inšpiratívne. Poetika a estetika českých divadiel poézie bola $\mathrm{v}$ danom období totiž nepomerne vyspelejšia, výrazovo i tvarovo vypracovanejšia než pomerne konvenčné slovenské „recitovadlá poézie“. České amatérske divadlá poézie, navyše, pomerne úzko súviseli s bohatým zázemím českých maloformistických či štúdiových divadiel, ktoré $\mathrm{v}$ tom čase zažívali vel'ký rozmach. Medzi d’alšie využívané a „vzývané“ formy alternatívneho alebo netradičného divadla patrili napríklad autorský a poetický kabaret, autorský muzikál, šansón, pantomíma, inscenácie anekdot, pohybové fyzické divadlo, plenérové divadlo, performancie a text-appealy, ktoré prit’ahovali - ako konštatuje Peter Pavlovský — „predovšetkým mladé publikum svojou spoločenskou i umeleckou provokatívnost'ou a latentnou opozičnost'ou, kontrastujúce s prevládajúcou uniformitou oficiálneho dobového československého divadla (tým plnili funkciu umenia spätého neskôr s alternatívnou divadelnou kultúrou) “35. Divadlá malých javiskových foriem kládli vel'ký dôraz na kontakt s divákom. Nemožno povedat', žeby sa repertoárové divadlá chceli od diváka dištancovat', ale ich inscenačná poetika, priestorové riešenie, mohutná výprava etc. nahrávalo skôr predstave, že divadlo je niečo, čo je nedotknutel'né alebo posvätné. Tento trend práve komorné divadlá malých javiskových foriem narušovali či dokonca popierali. $\mathrm{V}$ menšom priestore vytvorili predstavu divadla pre divákov z rozličných oblastí súdobého spoločenského života, čo bolo podporené ešte povahou autorského divadla a osobnostným autorským herectvom. V slovenskom kontexte sa vyskytovali v nepomerne menšom počte. Za všetky spomeňme napríklad aktivity Milana Lasicu a Júliusa Satinského či Stanislava Štepku, ktorí sa k tejto vlne otvorene hlásili.

Karol Horák vo svojich reflexiách na ranné obdobie vlastnej umeleckej činnosti mapuje aj konkrétne reáliá a zo súborov patriacich k českej umeleckej špičke divadla poézie radí telesá, akými sú brnenské Divadlo poézie X 62 (1958), pražské Takzvané divadlo poézie (1963) či Divadlo Orfeus Praha (1967) — divadelné skupiny, ktoré umelecky viedol herec, divadelný režisér, dramatik a demiurg českého undergrondového a nonkonformného divadla Radim Vašinka. Horák uvádza aj d’alšie zoskupenia — okrem iných — brnianske Divadlo „X“ (1959), Divadélko pod Okapem Ostrava (1961), Paravan Praha (1959), ale predovšetkým Quidam Brno (1966), Docela malé divadlo Litvínov (1962) vedené amatérskym recitátorom a režisérom Miroslavom Kovař́kom a pražské Divadlo na okraji (1969) zalo-

35 P. Pavlovský et al., Základni pojmy divadla: Teatrologický slovník, Praha 2004, s. 271. 
žené divadelným a televíznym režisérom, scenáristom a dramaturgom Zdeňkom Potužilom.

Divadlo ako umenie životne odkázané na svoju verejnú prezentáciu a komunikáciu sa vždy odohráva $v$ istých spoločenských a politických súradniciach, a tie boli v sledovanom období dané vtedajšou mocenskou štruktúrou na čele s vládnucou komunistickou stranou a socialistickou garnitúrou. Preto neprekvapuje, že sa divadlo v bývalom Československu - a jeho alternatívny prúd obzvlášt’ muselo vyrovnávat's nel'ahkými spoločensko-politickými podmienkami. V každom prípade si je nutné uvedomit', že $\mathrm{v}$ danom čase $\mathrm{v}$ zásade žiadna suverénna nezávislá či alternatívna činnost' divadelného súboru — ako sme už na to viackrát v štúdii upozornili — nebola možná. Každý súbor musel mat' svojho zriad’ovatel'a, ktorému sa musel za svoju činnost' zodpovedat' a ktorý na súbor vyvíjal aj rôzny tlak motivovaný zase jeho zodpovednost'ou voči vyšším príslušným orgánom štátne preorganizovanej a kontrolovanej kultúry. Z tejto siete direktívneho riadenia a všestranného dohl'adu sa vymykali - ako ich presne charakterizoval Jan Roubal — „iba jednorazové, príležitostné akcie poloverejného charakteru, napr. rôzne školské predstavenia či vystúpenia skôr paradivadelného typu v rámci školských akadémií, plesov, recesne ponímaných študentských večierkov, vernisáží a happeningov konajúce sa však zvyčajne len pre spriaznené publikum, ktoré sa vopred poznalo a vytváralo tak dôvernú komunitu“'36.

Celkovo možno o „mode vivendi“ vtedajšieho československého alternatívneho divadla v sledovanej oblasti a období konštatovat', že sa tu — síce v menšom meradle a nerovnomerne rozloženej škále — objavujú typické črty podmienok a pomerov, v ktorých sa činnost' týchto súborov odohrávala vo všetkých regiónoch. Súbory tohto typu divadla sa s nimi vyrovnávali po svojom. Niekedy volili cestu parciálnych kompromisov (v prípade amatérskych telies nimi boli napr. občasné ,príležitostné“ vystúpenia v rámci oficiálne organizovaných spoločenských akcií), niekedy hovorili — súhlasne s Janom Roubalom — „poetikou náznakov, analógií a metafor, inokedy zase slobodným humorom a tvorivou hravostou, často aj priamymi výrazmi generačného morálneho nepokoja“37. Jedno je však neodškriepitel'né, že ich bytostnou silou bola nákazlivá autentickost', „poučené“ a solidárne publikum a vitálna schopnost' urobit' často z núdze svojho periférneho postavenia cnost' hrdého sebavedomia vlastnej identity. Tieto skutočnosti sa premietli aj do činnosti prešovského študentského divadla a našli svoj umelecký odraz aj v dramaturgii divadelného festivalu AP.

K českým alternatívnym divadelným súborom, ktoré v novom miléniu vystúpili na tomto podujatí patria: BÍLÉ DIVADLO Ostrava: Červený kohout letí k nebi (2001), réžia: Jan Č́ihal; DNO Hradec Králové: Ryža, Operetka, Rychlé šipy, Oslik, Goméz... (2002), réžia kolektív; DEKADENTNÍ DIVADLO BERUŠKA

36 T. Lazorčáková, J. Roubal, K netradičnímu divadlu, Praha 2003, s. 38.
37 Ibidem, s. 39-40. 
Brno: Midi Lidi (2003), réžia kolektív; SPOLEK RICHELIEU Praha: M.H. Frys Vy tomu věríte? Aneb Don Quijote de la Mancha (2004), réžia Martin Frys a Jana Pilátová; DIVADLO V 7 A PŮL - KABINET MŮZ Brno: Roger Krowiak Tajemství zákerného paštikáře (2006), réžia: Ondřej Elbel; RECITAČNÁ SKUPINA Prostějov: Tragaču, Tragaču (2007), réžia: Hana Kotyzová; NOVÁ SÍŤ Praha: James Donlon, Vojta Švejda Albert se boji (2008), réžia: James Donlon; DEKADENTNÍ DIVADLO BERUŠKA Brno: Zlatá nálada (okamžitý low-fi muzikál pre tri hlasy (2008), réžia: kolektív; HANDA GOTE research \& development Praha: Emily, Hlbiny a farby samoty (2010), réžia: kolektív; KATEDRA PANTOMÍMY HAMU Praha - CIRKUS MLEJN: Postav na čaj! (2010), réžia: Eliška Brtnická a Jana Klimová; JEDEFRAU.ORG - CRISTINA MALDONADO Praha: What she does (2012), réžia: Cristina Maldonado a Tomáš Procházka; BÍLÉ DIVADLO Ostrava: Z tohto obrazu už nikdy neodejdu (2012), réžia: Jan Č́íhal, ALFRED VE DVOŘE Praha, Helsinki: Pasi Mäkelä Tonttu (Performance) (2013), réžia: Pasi Mäkelä; PALÁC AKROPOLIS Praha: ČEZko forever / Skutočná udalost' (2013), réžia: Petr Boháć; DNO Hradec Králové: Den Dna (2014), réžia: Jiří Dobeš, Jiř́i Jelínek a kol.; NEKROTEATER Praha: NEKROgames (2014), réžia: Jana Micenková; D’ EPOG Brno: Vše, co je krásne, rozmnožit má se (2015), réžia: Lucia Repašská; ARTWAY THEATRE Praha: Martina Balážová / Marcela Magdová Ženská epopeja (2015), réžia: Martin Satoranský; KATEDRA ALTERNATIVNÍHO A LOUTKOVÉHO DIVADLA DAMU Praha a DIVADLO DISK Praha: V. Wolf, K. Hutečková K majáku, do strany 73 (2016), réžia: Klára Hutečková; ARTWAY THEATRE Praha: Ivana Gibová Borderline (2017), réžia: Jana Micenková; Divadelní fakulta Janáčkové akademie umění Brno: M. Maeterlinck Príchod (2017), réžia: kolektív; Divadlo Bolka Polívky Brno: V. Fotka, P. Jarčevský, M. Chovanec, O. Klíč Letem sokolím (2018), réžia: Petr Jarčevský.

\section{Záver}

V záverečnej sumarizačnej syntéze by sme mohli konštatovat', že medzi kontextom slovenskej národnej divadelnej kultúry a prešovským regionálnym súborom prebiehala kontinuálne pulzácia inšpiratívnych podnetov, ktoré mali tak podobu racionálnej a vopred pripravovanej koncepcie, ako aj spontánnej reakcie na podnet zvonku. Ten neraz nadobúdal podobu prekvapujúco autentickej estetickej hodnoty, ktorá zväčša predstavovala iba latentnú filiáciu s prvotným podnetom a v prepojení na recipienta s osobitým štatútom v národnom kontexte vytvárala nečakane jedinečný divadelný artefakt (napr. Džura [1968], Démon [1967], Fragmenty [1974], Živý nábytok [1975], Tip-top biotop [1976], Materstvo [2011], Človek etudový alebo Konšpirácia alebo Od skúšky k predstaveniu [2013] a mnohé iné). 
Aj týmto spôsobom sa usilovala jedna línia slovenského divadla — alternatívna scéna - nivelizovat” „zaostávanie“ slovenského divadla za európskym, príp. svetovým kontextom. Neraz išlo o spontánnu aktivitu, ktorá mala prekvapujúco umelecké výsledky efektívnejšie a vitálnejšie než dlhodobo pripravované a racionálne sofistikované projekty, ktorým však často chýbala duša alternatívy.

\title{
Bibliografia
}

Aronson A., Americké avantgardni divadlo, prel. D. Jobertová, Akademie múzických umění, Praha 2011.

Babiak M., Slovenská dramatika na prahu 21. storočia, [w:] Kontexty alternatívneho divadla II, red. J. Gbúr, K. Horák, M. Pukan, Filozofická fakulta, Prešov 2006/2007, s. 131.

Degler J., Teatr, [w:] Leszek Mądzik. Teatr, scenografia, warsztaty, fotografia, plakat, Wydawnictwo jedność, Kielce 2008, s. 7.

Divadlo chléb a loutky, / Scénografie č. 30, red. V. Ptáčková, Divadelní ústav, Praha 1972.

Horák K, Metamorfózy alternatívneho divadla, red. M. Pukan, E. Kušnírová, P. Himič, P. Modrý, Levoča 2009, s. 95-142.

Horák K., Slovo, gesto, obraz, tvar, Osvetový ústav, Bratislava 1981.

Hyvnar J., Herec v moderním divadle, Divadelní ústav, Praha 1999.

Inštitorisová D., Č́tanie v mysli dramatika (Karola Horáka), Vydavatel'stvo Tatran, Bratislava 2007.

Laciaková D., Lech Raczak v prúdoch Akademického Prešova, [w:] Kontexty alternatívneho divadla II, red. J. Gbúr, K. Horák, M. Pukan, Filozofická fakulta, Prešov 2006/2007, s. 252-254.

Lazorčáková T., Roubal J., K netradičnímu divadlu, Pražská scena, Praha 2003.

Living Theatre, red. J. Kořán, P. Oslzlý, prel. P. Janský, K. Pospíšilová, M. Žilina, Jazzová sekce, Praha 1982.

Marčok V. et al., Premeny dramatickej tvorby, [w:] Dejiny slovenskej literatúry III, Národné literárne centrum, Bratislava 2004, s. 327.

Nezval V., Moderní básnické sméry, Československý spisovatel, Praha 1969.

Pavlovský P. et al., Základní pojmy divadla: Teatrologický slovnik, Divadelní ústav, Praha 2004.

Rottenberg A., Náčrty tvaru, [w:] Akademia Ruchu. Miasto. Pole akcji, Centrum Sztuki Współczesnej Zamek Ujazdowski, Warszawa 2012, s. 148.

Semil M., Wysińska E., Slovník světového divadla 1945-1989, prel. I. Lexová, J. Roubal, H. Suchařípová, J. Vondráček, Divadelní ústav, Praha 1998.

Sloviak J., Cuesta J., Jerzy Grotowski, prel. K. Dylewska, Wydawnictwa Uniwersytetu Warszawskiego, Warszawa 2010.

Wójciak E., Arka, [w:] Teatr Ósmego Dnia, red. a fot. P. Skorupska, Agora, Warszawa 2007, s. 49.

\section{Intercultural dialogue in present Slovak drama and theatre}

\author{
Summary
}

The study deals with the possible inspirations from the external environment being the part of works by Karol Horák which undergo a creative transformation and produce a new aesthetic quality on the level of text, as well as the on the level of new staging forms or genesis of a completely 
new autochthonic theatre form (author's theatre, postmodern theatre, medial theatre, happenings, performances, site-specific, etc.) There was a continuous pulsation among Slovak national theatre culture, or rather metonymically understood Prešov's regional student theatre, and American (Living Theatre of J. Becka and J. Malinova, Schumann's Bread and Puppet, etc.), Polish (Kantor's Cricot 2, Grotowski's Theatre Laboratory, Raczak's Theatre of Eighth Day, Mądzik's Plastic scene, Słupczynski's Theatre Studio of Těšín, the Theatre Academy of Movement, Cracowian KTO, etc.) and Czech provenance (Theatre Orpheus Prague, Theatre X Brno, Theatre under Drain Pipe Ostrava, Quite Small Theatre Litvinov, Theatre on the Periphery, Prague, Quidam Brno, etc.) They have the form of a rational as well as a spontaneous reaction to the external stimulus which often acquired a form with surprisingly authentic aesthetic value. This value usually represented the latent affinity with the original stimulus and it often created an authentic theatre artefact with respect to the recipient having the peculiar status within the national context (e.g. Džura [1968], Démon [1967], Fragmenty [1974], Živý nábytok [1975], Tip-top biotop [1976], Materstvo [2011], Človek etudový alebo Konšpirácia alebo Od skúšky k predstaveniu [2013] etc.) This was the way how one wing of Slovak theatre tried to balance falling short of the European or world context. 